Bangladesh J. Zool. 42(2): 271-276, 2014

\title{
PROTECTIVE EFFECT OF BRINE-SALT CURING ON PHYSICO-CHEMICAL ATTRIBUTES ON THE TAKI FISH (CHANNA PUNCTATUS) AND THE TENGRA FISH (MYSTUS TENGRA) AT ROOM TEMPERATURE
}

\author{
Farzana Binte Farid*, Gulshan Ara Latifa, Mosarrat Nabila Nahid \\ and Mohajira Begum ${ }^{1}$ \\ Department of Zoology, University of Dhaka, Dhaka-1000, Bangladesh
}

\begin{abstract}
Brine salt curied (BS) Taki fish and the small Tengra fish were studied to observe such salting procedure on their bio-chemical composition stored at room temperature $\left(26-32^{\circ} \mathrm{C}\right)$. In fresh-processed condition, moisture, protein, fat, ash, $\mathrm{pH}$ and free fatty acid were $62.28 \%, 18.02 \%, 2.76 \%, 17.24 \%, 6.8$ and $0.5 \%$ in BS taki fish and $57.35 \%, 15.3 \%, 6.84 \%, 20.8 \%, 5.9$ and $0.9 \%$, respectively in tengra. The value of moisture, $\mathrm{pH}$ and FFA increased significantly $(\mathrm{p}<0.05)$ with the time of storage and these values rapidly increased in cured taki than BS tengra and at the end of 75 days BS taki became spoiled whereas BS tengra still remained in fresh condition. It was observed that BS tengra fish-product had longer shelf life (120 days) and was found better for preservation in laboratory condition. This work also showed that the effect of the treatment on a fish sample dependent on the fish species.
\end{abstract}

Key words: Brine-salting, taki, tengra, biochemical-composition, room temperature

\section{INTRODUCTION}

Fishes ususlly spoil within 12 - 20 hours depending on species and the methods of harvesting. If they are not processed immediately after harvesting, certain irreversible spoilage and deterioration of meat quality begin to take place (Conne 1995). Most of the processing or preservation operations are intended to control the rate of spoilage by reducing water activity of fishes (Eyo 1986).

Processing is applied to fishes from the time of harvesting to the consumption by a customer. Commonly used methods for processing include salting/brining, sun-drying, freezing and smoking, which also increase fish availability to the consumers (Abolagba et al. 1996). Adequate information, however, available on the quality of various frozen and dried marine fishery products are available but very little is known about the nutritional quality of brine-salted fresh-water fish-products in Bangladesh.

Taki fish is a medium size air breathing fish while tengra is a small cat fish, both of these fishes live in freshwater environment and are easy available, tasty and nutritious as well as popular fishes. The present work was thus conducted to assess the effect of Brine salt curing on the macronutrient content of two commonly consumed fished of Bangladesh.

*Author for correspondence: <farzanafarid79@gmail.com>. 1Institute of Food Science and Technology (IFST), BCSIR, Dhaka-1205, Bangladesh. 


\section{MATERIAL AND METHODS}

The freshwater fish taki (Channa punctatus) and tengra (Mystus tengra) were collected from the river Meghna in early morning and brought to the Fish Technology Section, Institute of food Science and Technology (IFST), Bangladesh Council of Scientific and industrial Research (BCSIR), Dhaka, using sterile polythene, where fishes were carefully washed with cool tap water. Fins, gills, viscera, head and scales of taki were removed and washed to remove blood, slime and unnecessary flesh. The experiment was conducted for a period of 4 months between May 2013 and August 2013. Fresh fish-specimens were taken randomly and ground with an electric blender to make a homogenous sample before being sampled for analyses.

Brine salting method (BS): In the present experiment brine was prepared using $30 \mathrm{~g}$ salt in $100 \mathrm{ml}$ water. Fishes were kept at this brine solution stacked in containers and stored for a salting or curing period, at room temperature $\left(26^{\circ} \mathrm{C}-32^{\circ} \mathrm{C}\right)$ for the production of brine salted fish. The fishes in brine were kept immersed by putting a glass weight.

Storage of the product: After salting procedure, brine-salted products of the two fishes were preserved in plastic bag maintaining aseptic condition as far as possible and were stored at room temperature $\left(26^{\circ}-32^{\circ} \mathrm{C}\right)$. The preservation period of product was linked to the amount of salt added; therefore a straight proportion was present between the amount of salt used and the preservation period (Bahri 2006).

Sampling procedures: Evaluation of phisico-chemical characteristics in brinesalted taki and tengra fishes were carried out for 15 days interval for room temperature, until the fish became spoil or inedible condition. Two duplicate experiments were conducted at regular time intervals during salting period.

Biochemical analysis: Analytical methods were applied for the determination of biochemical composition of the raw fishes as well as of processed fish products on experimental basis. Moisture, fat, ash and FFA value of the fishes were determined by AOAC conventional method (AOAC 1990). The crude protein of the fish was determined by Micro-Kjeldal method (Pearson 1999). $\mathrm{pH}$ value of the sample was determined with the help of a pH meter (Mettler Toledo 320-s, Shanghi, China) follwing standard method (Vynke 1981).

To calculate the significance at $\mathrm{p}<0.05$ level all data was analyzed with the help of SPSS for windows, version 20 statistical software. 


\section{RESULTS AND DISCUSSION}

Determination of the bio-chemical composition of taki (C.punctatus) and tengra (M.tengra) fish in fresh condition and brine-salted condition (storage at room temperature) were made.

Proximate composition: Moisture, protein, fat and ash were 78.65, 15.89, 3.02 and $1.16 \%$, in case of fresh taki fish and $74.27,13.43,9.04$ and $2.67 \%$, in case of fresh tengra fish (Fig. 1). Fresh fish samples presented a high moisture and low protein content, similar to previous report (Eyo 1998).

After the end of brining, moisture, protein, fat and ash content were 62.28, 18.02, 2.76 and $17.24 \%$ in freshly processed BS taki fish and 57.35, 15.3, 6.84 and $20.8 \%$ in freshly processed BS tengra fish-product (Fig.1).

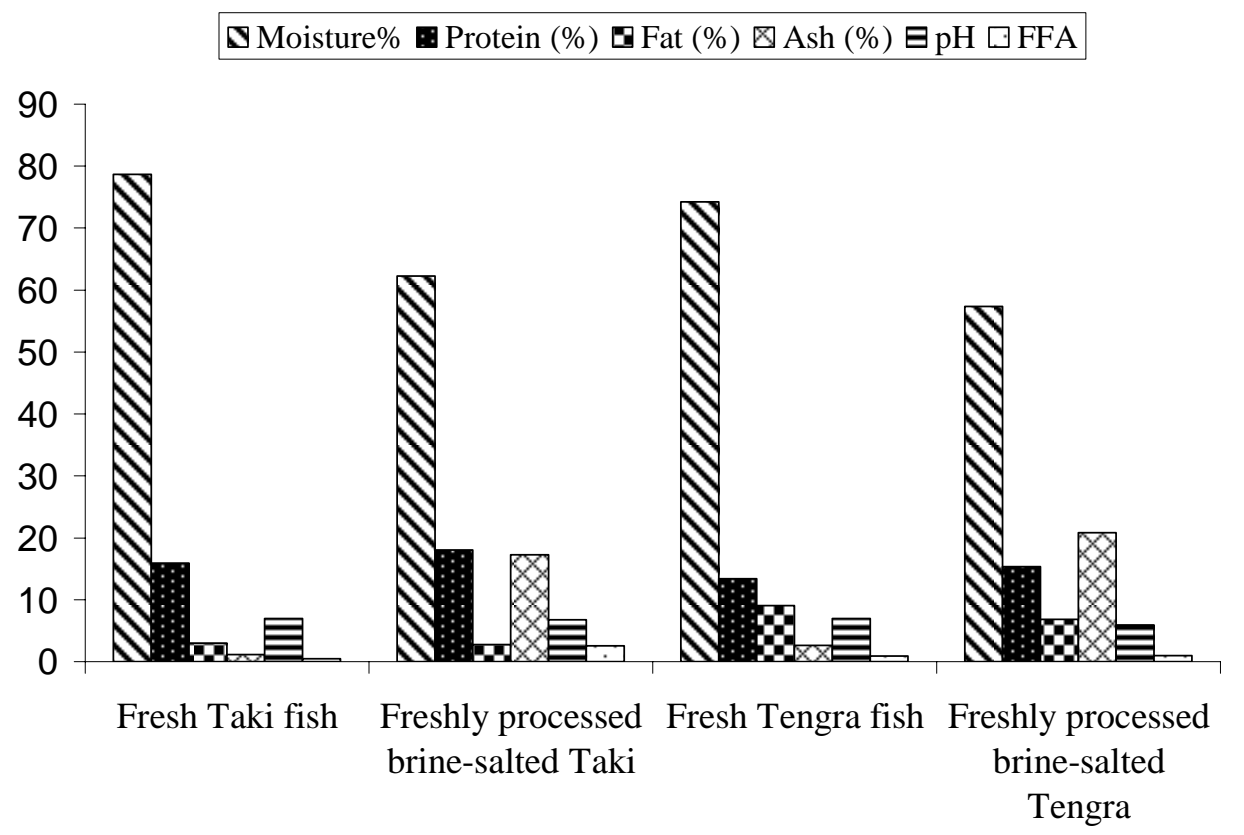

Fig. 1. Comparison of the Bio-chemical composition of fresh Taki (Channa punctatus) and Tengra (Mystus tengra) fish.

After completing the duration of storage period, moisture, protein, fat and ash contents were found as 65.08, 16.92, 2.48 and $15.99 \%$ in case of BS taki (75 days) and 60.7, 14.28, 6.01 and $19.4 \%$ in case of BS tengra (120 days) (Figs. 2 and 3).

Moisture uptake and decrease of protein, fat and ash content during the storage period were significant in the products stored in room-temperature. Moisture absorption in such products is obvious during monsoon due to high 
relative humidity difference. Decrease of fat might be due to oxidative deterioration, thereby affecting lipid extraction (Gandotra et al. 2012). Decrease in the level of crude protein and fat contents of small and large salted Bouri fish muscle (Mugil cephalus) were reported (El-Sebahy 1988).

Brine-Salted (BS)Taki

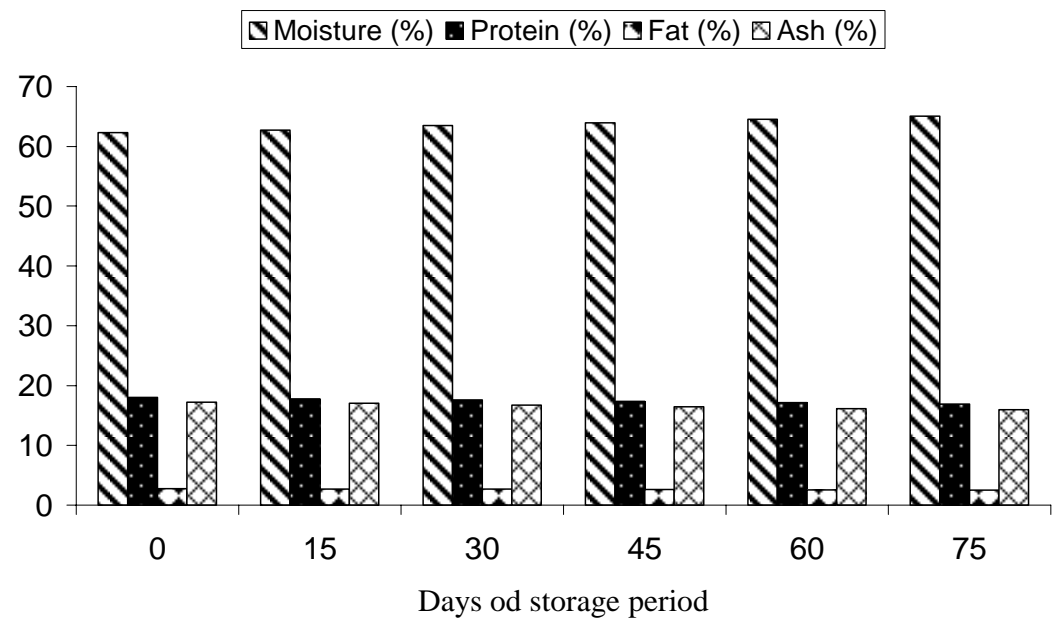

Fig. 2. Changes in Proximate Composition of Brine-salted (BS) Taki fish (Channa punctatus) during storage at Room Temperature.

Brine-Salted (BS) Tengra

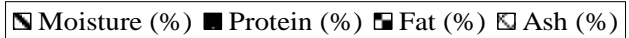

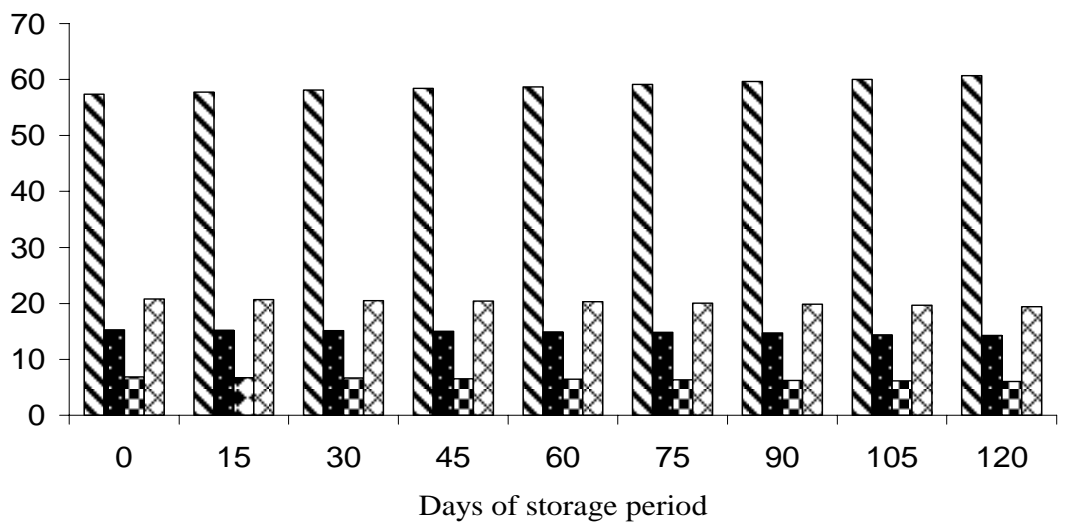

Fig. 3. Changes in Proximate Composition of Brine-salted (BS) Tengra fish (Mystus tengra) during storage at Room Temperature.

Changes in $\mathrm{pH}$ value: The $\mathrm{pH}$ of freshwater fish flesh at fresh-condition is almost neutral (Virta 2009). Increase in $\mathrm{pH}$ indicates the loss of quality in fishes. The $\mathrm{pH}$ value of $\mathrm{BS}$ taki and tengra fish-products was significantly $(\mathrm{P}<0.05)$ 
increased during storage time. In the present study, $\mathrm{pH}$ values of both fresh taki and tengra fish were 7 and varied from 6.8 (0 day) to 8.3 (75 days) for BS taki and 5.9 (0 day) to 7.9 (120 days) for BS tengra (Fig. 4). The initial pH values in the samples were similar but the increase in $\mathrm{pH}$ values during the storage of room temperature $\left(27-31^{\circ} \mathrm{C}\right)$ was higher than reported in other researches (Huss 1988, Shenderyuk 1989, Eyo 1993 and Erkan et al. 2011). The probable reason behind these differences was due to differences in fish species and different methods of salting used.

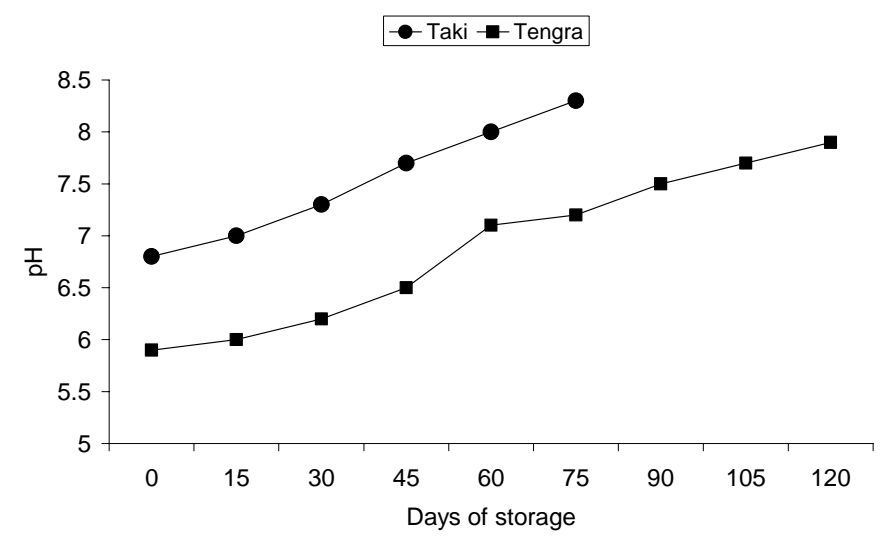

Fig. 4. Changes in $\mathrm{pH}$ value of Brine-salted (BS) Tengra (Mystus tengra) fish during storage at Room Temperature.

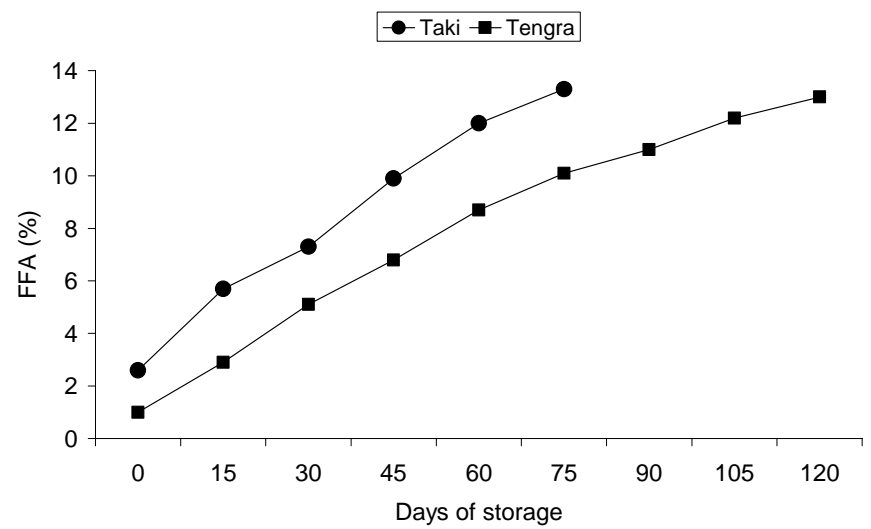

Fig. 5. Changes in FFA (\%) value of Brine-salted (BS) Tengra (Mystus tengra) fish during storage at Room Temperature.

FFA value: FFA value is a measure of the extent of oxidative deterioration in fish, increased during storage but it can fall further at latter stages of fish spoilage (FAO/SIFAR, 2001). The same result was found in the present study. It 
varied from $2.6 \%$ (o day) to $13.3 \%$ (75 day) for BS taki and $1 \%$ (o day) to $13 \%$ (120 day) for BS tengra respectively (Fig. 5).

The above result showed that brine-salted tengra fish-product has grater nutritive value and has longer shelf life (120 days) and has better way for preservation at laboratory condition.

\section{LITERATURE CITED}

ABOLAGBA, O.J. OKONJI, V. A. and ENOBAKAARE, D.A. 1996. Salting of fish as a means of reducing damage by Dermestes maculates (Coleoptera) Nigeria J. of Ent. 13: 81-86.

AOAC. (Association of Official Analytical Chemist). 1990. Official methods of Analysis (15 th ed.). Inc., Suite, 400, Arlington, Virginia. Vol. 2, 685-1298.

BAHRI, P. AYESE, G.I. GULSUM, O. and IRFAN, I. 2006. Microbiological and chemical qualities of salted grey mullet. Int.J. Sci. Techno. 2, 91-98.

CONNE, J.J. 1995. Control of fish quality. Fishing news book, a division of black ell science Ltd 1: 4 th edn.

EL-SEBAHY, L.A. and METHWALLI, M.S. 1988. Changes in some chemical characteristics and lipid composition of salted fermented Bouri (M. cephalus) fish muscle. Food Chemistry. 31, 41-50.

ERKAN, N. TOSUN, S.Y. ULUSOY, S. and URETENER, G. 2011. The use of thyme and laurel essential oil treatments to extend the shelf life of bluefish (Pomatomus saltatrix) during storage in Ice. Journal für Verbraucherschutz und Lebensmittelsicherheit. 6(1): 39-48.

EYO, A.A. 1986. Significance of fish handling preservation and processing in the development of Nigeria inland fisheries with special reference to Kanji Lake. Fisheries Society Nigeria: 3rd annual conference proceedings.

EYO, A. A. 1993. Traditional and improved fish handling, preservation and processing techniques. Paper presented at national workshop on fish processing storage, marketing and utilization.

EYO, A.A. 1998. Shelf-life of Moon fish (Citharinus citharus) and Tumk Fish (Mormyrus rume) during storage at ambient temperature and on Ice. FAO Fisheries Report No. 574, 35-37.

FAO/ SIFAR, 2001. Non-Sensory Assessment of Fish quality. Note No. 92.

GANDOTRA, R. MEENAKSHI, K. SWETA, G.and SHALLINI, S. 2012. Change In proximate composition and microbial count by low temperature preservation In fish Muscle Of Labeo rohita (Ham-Buch) IOSR J. Pharm. Biol. Sci. ISSN: 2278-3008. 2(1), 13-17.

HUSS, H.H.1988. Fresh Fish-quality and quality changes, FAO Fish Series 29, FAO DANINAQ, Rome. Italy. $132 \mathrm{pp}$.

PEARSON, D. 1999. Pearson's composition and analysis of foods. University of Reading.

SHENDERYUK, V.I. and BYKOWSKI, P.J. 1989. Salting and Marinating of fish. In: Sikorski, Z.E. (Ed.) Seafood Resources: Nutritional Composition and preservation, CRC Press Inc. Boca Raton, Florida.

VIRTA, S. 2009. Isolation and identification of rainbow trout spoiling Microbiota. Biotechnology and Food Technology, Turku University of Applied Science. 8pp. (Unpublished).

VYNKE, W.1981. pH of fish muscle comparison of methods, Western European Fish Technologists' Association (WEFTA), Copenhagen, Denmark.

(Manuscript received on 3 September, 2014; revised on 30 November, 2014) 